\title{
PLANT VIRUS DISEASES
}

A

GENERAL paper-reading meeting of the Association of Applied Biologists was held at the British Museum (Natural History), Cromwell Road, London, on February 10. Dr. C. Potter was in the chair. Although not advertised as a symposium it might well have been, for it had a coherent content of new and unpublished work on diseases caused by plant viruses in crops.

Several themes, apart from the obvious ones implicit in the titles, linked the different contributions. The first was the ubiquity of soil-transmitted viruses, some known and some suspected to be transmitted by nematodes. Another was seed-transmission which recurred in several contexts, and a third, carried or 'pick-a-back' viruses. These are viruses that cannot be transmitted alone by arthropods, but may be so in the presence of another virus that is transmissible by a vector.

All these aspects of transmission were mentioned in the first paper on "Some Celery Viruses", by Mr. M. Hollings (Glasshouse Research Institute). Among viruses isolated from celery crops was celery yellow vein, transmissible by grafting and by manual inoculation of infected sap, as well as through naturally infected soil. It reacts strongly to antisera prepared against a strain of tomato black ring virus, which is transmitted by seed, soil and probably nematodes. Cucumber mosaic and lucerne mosaic viruses were isolated from the field. A previously unrecorded virus, provisionally called celery yellow spot, could be transmitted from celery to celery only when cucumber mosaic was present; cucumber mosaic alone did not cause the symptoms, and yellow spot alone was not transmissible. Another previously undescribed virus, celery yellow net, was transmitted by grafting or manual inoculation only during the winter months; no aphid or other vector was found.

Mrs. M. A. Watson (Rothamsted Experimental Station) described carrot motley dwarf virus which causes a disease of carrots known to growers as purple top. In an experiment, infection in July caused a loss of about one ton per acre of carrots for every additional 15 per cent of plants infected. The willow-carrot aphid, Cavariella aegopodiae, retained the virus for many days when adequately fed on infected plants. Motley dwarf may be a complex of two viruses, motley dwarf proper and red leaf. Motley dwarf proper was transmissible by aphids and by manual inoculation to Nicotiana spp. but not by aphids thereafter. Red leaf has not been transmitted by manual inoculation, and does not seem able to infect Nicotiana spp. Possibly its presence enables motley dwarf to be transmitted by aphids, and it may be transmitted by seed in an attenuated form. Motley dwarf virus was infective in saps extracted with phenol, but infectivity was completely destroyed by addition of ribonuclease to a final dilution of $0.01 \mathrm{mgm}$./1., $3 \mathrm{~min}$. before inoculation, suggesting that infective material in phenol extracts is nucleic acid.

Dr. J. A. Tomlinson (National Vegetable Research Station) showed that lettuce crops can be kept reasonably free from damage by lettuce mosaic virus in the summer, by sowing seed containing less than 0.1 per cent of seed-infection. In winter, cucumber mosaic caused a disease resembling that caused by lettuce mosaic. Cucumber mosaic is not transmitted by seed so control measures based on seed hygiene were less successful in winter than in summer. An unidentified virus caused symptoms similar to those of arabis mosaic when inoculated to Chenopodium spp., but was symptomless in lettuce.

Dr. R. Markham (Agricultural Research Council Virus Research Unit) presented a joint paper with Dr. R. MacLeod on "A Persistent Aphid-transmitted Virus Disease of Tobacco". This virus, provisionally called tobacco yellow net, was not manually inoculable, but was transmitted by Myzus persicae, which could retain it for several days after a single adequate feeding on infected leaves. It resembled the 'veindistorting' component of K. M. Smith's tobacco rosette complex of viruses, and, like 'vein-distorting' virus, was able to act as a carrier for the other component of the complex, mottle virus, which was otherwise not transmissible by aphids. Yellow net might be easier to handle biochemically than other aphid-transmitted persistent viruses which usually have less amenable hosts than tobacco. However, vein-distorting virus, which it resembles, has proved disappointing in this respect.

At the afternoon session emphasis was on soiltransmitted viruses. Some of these, for example arabis mosaic, have previously been known to be transmitted through infected soil, but nematodes have only recently been shown to be the vectors.

Mr. R. M. Lister (Scottish Horticultural Research Institute), in a joint paper with Dr. A. F. Murant, described seed-transmission of arabis mosaic, raspberry ringspot and tomato black ring viruses in a wide variety of hosts, including many weeds. These viruses are disseminated by distribution of vegetative material from nematode-infested sites, but dissemination of infected seed may spread them even more widely. However, such spread is limited by the susceptibility of the wild plants to virus and vectors, and the amount of seed that becomes infected. Infected weeds may have poor ability to survive in competition with healthy ones and in cultivation. Even if they survive, it may be in sites free from suitable nematodes. These factors probably reduce the chances of virus being spread by seed transmission.

Speakers in the discussion also thought that the three viruses are mainly spread by infected propagating material, but the importance of the discovery that they are transmitted by seed was stressed. Mr. Lister mentioned that the viruses were pollen-transmitted, and distribution by pollen may be more effective than by seed.

Dr. B. D. Harrison (Rothamsted Experimental Station) gave a joint paper with Dr. R. D. Winslow on arabis mosaic virus. It included one of the first accounts of the behaviour of a nematode-transmitted virus in relation to its vectors. The virus has previously been associated with important diseases of raspberry, strawberry and cherry, very recently with white clover, marrow and celery. The patchy distribution of diseased plants in crops coincides with that in the soil of Xiphinema diversicaudatum, the vector of arabis mosaic virus. Adult nematodes usually transmit better than larvæ, but both are infective after being kept without plants for several 
weeks. The virus remains viable a much shorter time in vitro, and must be in some way stabilized in the nematodes; possibly it multiplies in them. Galls that develop on roots of plants infested with $X$. diversicaudatum are caused by nematode feeding and not by virus infection. Evidence is accumulating that transmission of different nematode-transmitted viruses is specific to particular species of nematodes. Ecological studies showed that in some districts hedgerow plants are important hosts of arabis mosaic and of $X$. diversi. caudatum, but in others the vectors, and probably the virus, are more widely distributed in the fields. An interesting discussion centred around the possibility that cultivation, and not preference of the nema,todes for a particular environment, determined this distribution. A grass field that had not been cultivated for thirty years had nematodes only near its hedgerows, but Dr. F. Raw did not think thirty years to be a particularly long time for soil animals not to have returned after cultivation.

An important paper by Mr. R. Cropley (East Malling Research Station) described the identification and symptoms of viruses isolated from cherry trees with rasp leaf and leaf roll diseases which are widespread and damaging in sweet cherry orchards. Rasp leaf was found associated with raspberry ringspot virus, but the symptoms, of reduction in leaf size and rough enations on the backs of the leaves, can also be caused by arabis mosaic virus. Cherry leaf roll virus is readily transmissible by manual inoculation to many herbaceous hosts. Symptoms, thermal inactivation and particle size and shape are characteristic of soil, or nematode-borne 'ringspot' viruses, but leaf roll seems to be distinct from those already known. It is manually inoculable from cherry to Prunus pennsylvanica, and from tobacco to cherry and strawberry. Virus can be detected in young leaf tissues in the spring, but not in summer and autumn.

In the discussion Dr. Posnette emphasized the importance of cherry leaf roll; he thought that degeneration of orchards often attributed to age or poor husbandry was really caused by the virus. It was suggested that Tomlinson's lettuce latent virus (see paper No. 2) might be the same as cherry leaf roll virus.

An interesting symposium can be made to sound dull by the use of the dread word 'practical'. How. ever, this series of papers gave information of prac. tical importance to farmers and growers, as is only proper for applied biologists, but also contributed to general understanding of plant virus problems and reported advances of a more fundamental kind in virus research. There was clear indication of trends that could become important in the future.

Marion A. Watson

\section{PHYSICAL CONDITIONS OF SOIL}

$\mathrm{O}^{\mathrm{N}}$ March 1 about eighty members of the National egetable Research Station Association attended talks and demonstrations on "Soil Physical Conditions affecting Plant Growth", given by the staff of the Chemistry and Irrigation Sections at Wellesbourne.

It is well known that the overall physical condition of a soil, often referred to as soil structure, and, in the surface layers, soil tilth, has considerable effect on the growth of plants. Furthermore, applications of bulky organic materials, such as farmyard manure and compost, have given yields of vegetables much higher than those produced by inorganic fertilizers alone. The general reason advanced for this difference is that the bulky organic manures improve the physical condition of the soil as well as providing plant nutrients. While many opinions have been expressed, in text-books and elsewhere, as to which of the soil physical properties are important, for example, waterholding capacity and aeration, there is still a dearth of experimental evidence on the relations between measurable specific physical properties of the soil and plant growth.

Experimental work in progress at Wellesbourne on the following subjects was described and demonstrated: soil aeration; soil moisture characteristics; the uptake of nutrients by plants, especially in the early seedling stage; the distribution and activity of the roots of crop plants; and the effect of soil physical conditions on the responses of plants to applications of irrigation water.

At present, there is no satisfactory method for measuring soil aeration, and hence there is no means of assessing the importance of this factor in crop production. The distribution of oxygen in a soil may affect plant growth by influencing the ability of plant roots to take up nutrients, and by altering the activities of the micro-organisms and thus the amount of nutrients available to the plant roots. Work, so far, has been confined to the latter topic. With the view of using the activities of the soil micro-organisms as indicators of availability of oxygen, the effect of oxygen concentration on them is being studied. Actively metabolizing micro-organisms in scil are covered with a thin layer of water which is exposed to the soil atmosphere. Since large differences exist between the oxygen concentrations at different points in the water layer, techniques have been devised which enabled the activities of the soil micro-organisms to be correlated with the oxygen concentration in the water at their surfaces. It has been shown that the respiration of the soil organisms and nitrification were not inhibited, and denitrification and anaerobic decomposition of soil organic matter were not induced, unless the concentration of oxygen at the microbial surfaces was less than about $10^{-6} M$. Using microbial activities as indicators of oxygen concentration, physical theories of the distribution of oxygen in columns of moist soil crumbs are being tested, and efforts are being made to find out if it is possible to obtain the parameters necessary for the theories, from simple measurements on field soils.

In field experiments at Wellesbourne during 195461, applications of farmyard manure produced large increases in the yield of a wide range of vegetables. Measurements of the moisture characteristics of the manured and of the unmanured soils during the growth of a crop of leeks showed that at planting time in July the available water capacity of the two soils was the $\operatorname{sam} \theta$, but by October the available water capacity of the manured soil was 24 per cent greater than that of the unmanured soil. Further, the extra water was held at tensions less than 0.33 atmosphere, and, therefore, would be expected to be readily 